O.P. Mitryasova ${ }^{1}$, orcid.org/0000-0002-9107-4448,

V.D. Pohrebennyk ${ }^{2}$, orcid.org/0000-0002-1491-2356, O.S. Petrov ${ }^{3}$, orcid.org/0000-0001-9453-0755,

Ye. M. Bezsonov ${ }^{1}$, orcid.org/0000-0001-5745-3121, V. M.Smyrnov ${ }^{1}$, orcid.org/0000-0003-3809-6098
1 - Petro Mohyla Black Sea National University, Mykolaiv, Ukraine, e-mail: eco-terra@ukr.net

2 - Lviv Polytechnic National University, Lviv, Ukraine

3 - University of Science and Technology, Kraków, the Republic of Poland

\title{
ENVIRONMENTAL WATER SECURITY POLICY IN THE EU, UKRAINE AND OTHER DEVELOPING COUNTRIES
}

Purpose. To determine the key principles of environmental security of aquatic ecosystems in the context of sustainable use of natural resources and socio-economic development.

Methodology. Comparative analysis and systematic approach.

Findings. Principal aspects of water resources management in the states of the world are analyzed in the context of the provisions of the sustainable development concept. Comparison of countries with different levels of development has allowed identifying key methodological provisions that are implemented in the environmental policy of water. An approach to determination of the limiting indices of the impact on the environment is proposed. It was revealed that most post-Soviet countries do not use the concept of "ecological system" and "ecosystem services" in their legislative framework, which today are an integral part of the environmental policy and legislation of developed countries. The basic principles of the ecological safety of aquatic ecosystems are as follows: a water body (surface or underground ones) is a complex, functionally integrated and self-regulating ecological system. It cannot be considered as a volume with a resource for biological and amenity needs; priority in the water use should be given to the living components that exist in it and ensure its functional integrity. Any aquatic ecosystem should be economically assessed not only in terms of available water resources, but also considering other ecosystem services, particularly, the diversity of its biotic components. All these principles and the approach presented, if introduced into domestic legislation, will allow achieving progress in the field of ecological safety of aquatic ecosystems and sustainable social economic development.

Originality. An approach has been improved which determines the efficiency of environmental policy in the field of water resources safety through a correlation analysis of water consumption and population size.

Practical value. The research results allow for quantitative assessment of water resource management. The results of the study on the influence of the factor of freshwater resources on the socio-economic development of countries and regions of the world suggest that there is a strong statistically significant correlation in this system of connections.

Keywords: water ecosystem, water resources, water security, environmental policy, sustainable development

Introduction. Water is necessary in all spheres of life. The common goal of humanity is to ensure that adequate supply of good quality water is delivered to the entire population of the planet, while maintaining the hydrological, biological and chemical functions of ecosystems, adjusting their own activities to take into account the opportunities of nature. Most countries in the world have different policies in the field of water use, which complicates the compromise at the regional and global (biosphere) levels.

From an ecological point of view, water can be characterized as a fundamental material-energy basis for the balance of natural processes in the environment, the maintenance of living matter life.

If we consider water from the point of view of socio-economic development, then today almost all water on the planet is used by humans to meet certain household and industrial needs. That is, in fact, it performs a similar function of life support in social and technogenic environments, with the only difference that before and after human use, water is a substance of excellent quality (polluted, bound, altered at the atomic level, and so on), which is often not suitable for reuse by humans without preliminary purification, and in nature, in case of discharge, a certain time must elapse for its restoration to its original state. In fact, from the point of view of nature management those water resources are valuable that have been formed in the environment without human intervention, are independently cleaned and renewed, because they do not need

(C) Mitryasova O.P., Pohrebennyk V.D., Petrov O.S., Bezsonov Ye. M., Smyrnov V. M., 2021 energy and material costs for such technological operations within the anthropogenic cycle of use.

The UN Conference on Environment and Development in Rio de Janeiro (1992) adopted a declaration on environment and development. In this document, on the basis of which human civilization is trying to build development, it is enshrined that water is necessary in all spheres of life and the general goal of humanity is to ensure an adequate supply of good quality water to the entire population of the planet, while maintaining hydrological, biological and chemical functions of ecosystems, adjusting their activities taking into account the capabilities of nature. The communique of the meeting of the heads of state and government of the G-20 member countries in Hangzhou [1] confirmed the importance of water for humanity.

However, most countries in the world have different policies in the field of water use, which makes it difficult to reach a compromise at the regional and global (biosphere) levels.

That is why we consider it an urgent issue to determine the importance of aquatic ecosystems in the socio-economic development of the states of the world.

Considering the above, it is rather difficult to overestimate water resources in the life support of human society. At the same time, there are no general indicators of how much the socio-economic development of any state in the world depends on the availability of water resources. After all, modern specific calculations (for example, liters per year per person) are more often associated with geopolitics and almost do not reflect the importance of water in the development of mankind, focusing on its consumer properties and advantages over more water-deficient countries. 
Therefore, we consider it necessary to form more specific ideas about the importance of water resources, in particular fresh water, in the socio-economic development of society and, using the methods of statistical analysis, to determine their corresponding impact.

Literature review. Nowadays, most of the water is used by humans without being removed from the environment: hydropower, shipping, aquaculture, and others. Very often this function of water resources is significantly underestimated, although it directly affects population growth in energy-intensive territories.

The topic of scarcity of fresh water resources in the modern scientific information space is undoubtedly relevant [2]. In particular, issues of possible economic losses at the state level [3] and on a global scale [4], as well as modeling the dynamics of water reserves [5], are analyzed. At the same time, this opinion is confirmed by the absolute indicators of water supply to states, regions of the world or continents. Particular attention is paid to such issues as drainage of wetlands, deforestation, settlement of rivers, riverbed changes, and so on [6]. Against this background, a fair question arises: is there a natural process of increasing the deficit of fresh water?

In our opinion, it is only partial. Man changes the environment. Often it is not possible to restore water bodies that existed in nature before the start of economic activity. In most cases, the shortage of fresh water is caused by a purely consumer approach to this resource and is artificial in nature.

Analysis of various sources of information shows that over 40 years, humanity has changed approaches to water use, but priorities have remained unchanged.

The main approach is the ecosystem approach, which "covers the entire complex of terrestrial and aquatic ecosystems, considering the hydrological basin as a unit characterized by parameters that determine the conditions upstream and downstream, including in particular specific ecosystems such as forests, land resources, wetlands, urban ecosystems and coastal zones" [6].

However, the main and undisputed priority consumer is a human. This issue is especially acute during periods of malnutrition, when the question arises: either a person or an ecosystem.

A rough comparison can be made with oil. It is not present in all countries of the world in sufficient quantities to meet the needs of modern society; therefore, it is delivered to places of demand. Of course, it can be argued that water is biologically and vital substance for the human body. And from the point of view of biology, a person always gravitates towards water resources. Thus, the disappearance of water where it used to be, for the most part, is the fault of man, not nature. There is no shortage of fresh resources in the world; there is an imbalance and irrationality in their use.

The above can be proved by simple calculations. Thus, according to estimates, the total planetary volume of fresh water is estimated at 35 million $\mathrm{km}^{3}$ [4]. If we take the world population of 7.5 billion, then 0.67 million $\mathrm{m}^{3}$ per person per year, which is 2333 times higher than the UN minimum standard of $2000 \mathrm{~m}^{3}$ per year [6] (about $5.5 \mathrm{~m}^{3}$ per person per day, which can be considered a fairly high indicator).

Even if we use the term "available" fresh water, which is estimated at 97 thousand $\mathrm{km}^{3}$, the final figure per person is 12.9 thousand $\mathrm{m}^{3}$, which is more than 6 times higher than the accepted minimum.

Therefore, the reason for the shortage of freshwater resources must be considered not from the point of view of the imperfection of the biosphere, but rather the fallacy of the concept of anthropocentrism, according to which fresh water should be in every corner of the planet where people live and in sufficient quantities. Obviously, this is impossible and wasteful: by providing water to the desert, people dehydrate humid plains, swamps, rivers, underground layers with groundwater. Not least, these consequences are caused by the environmental policy of the states of the world and international organizations.
A number of researchers [7], calculating the water supply of the countries of the world [8], substantiate the optimal way of using fresh water resources by entering the international arena of negotiations as the only correct and reliable solution [9]. However, it is worth mentioning the situation with the annexation of the Crimea by the Russian Federation, fishing for cetaceans by Japan and the US abandonment of the Kyoto Protocol, and it immediately becomes clear that international treaties are not an extremely reliable way of implementing the principles of food and water security in the world.

We consider that the deficit of any resource, in particular water, is the quantity, which is insufficient to meet the economic and household needs of a human. The concept is subjective, artificial and characterizes the state of ecosystem components from the point of anthropogenic consumption. With regard to natural processes and biodiversity, the concept of "deficit of water resources" is virtually non-existent. Usually, the situation of water deficit in a river ecosystem can be characterized by the terms "drying up", "dehydration", "natural phenomenon", "drought", and others. If you include a human in this system, you will see "water deficit".

Therefore, water deficit is present where water supply, sewerage and water recycling systems are unbalanced in all types of economic, domestic and industrial activities; lack of understanding of the natural processes of formation and reproduction of freshwater in ecosystems.

Purpose of the research is to determine the key principles of environmental security of aquatic ecosystems in the context of sustainable use of natural resources and socio-economic development.

Methods: comparative analysis and systems approach. Statistical analysis was carried out using MS Excel software, in particular, using the appropriate functions for correlation analysis. The relationship between fresh water reserves and population size, the gross domestic product was studied. Samples from states were grouped according to regional characteristics, as well as by the presence of the sea coast.

The use of analysis of variance tools is explained by the fact that dividing the database (sample) into components (according to the criterion of the regions of the world) makes it possible to more clearly determine the causal relationships between freshwater resources and socio-economic development. The method also makes it possible to estimate the proportion of variation of the trait under study due to the action of an unregulated factor - freshwater resources. Thus, the force of the action of the factor of fresh water resources on socio-economic development was produced by the well-known methods of Snedekor and Plokhinsky.

It should be said that the authors deliberately did not try to complicate the analysis carried out in the work by increasing the coverage of the investigated (influencing) factors. Given the possible errors in the data banks, there was a risk of getting very inaccurate and biased multivariate models, while focusing on one of them, strategic (fresh water reserves), made it possible to more accurately determine its significance and strength.

Sources of information are databases of the World Bank, the United Nations (Human Development Report), and the US Central Intelligence Agency. At the same time, calculations for Africa were not carried out due to the limited amount of data. The same cases where the studied relationship between freshwater resources and socio-economic indicators is not traced can be explained by the bias of the data, primarily on the basis of temporary "freshness".

Results. According to the statistics of the World Bank on indicators of gross national income of the countries of the world [9] and population size [10], as well as data on water reserves of the US Central Intelligence Agency [11], there is a fairly strong correlation between population distribution and fresh water reserves in European countries. Asia and America: $r=0.728(n=29 ; p=0.01), r=0.881(n=20 ; p=0.01)$ and $r=$ $=0.63(n=13 ; p=0.05)($ Fig. 1$)$. 


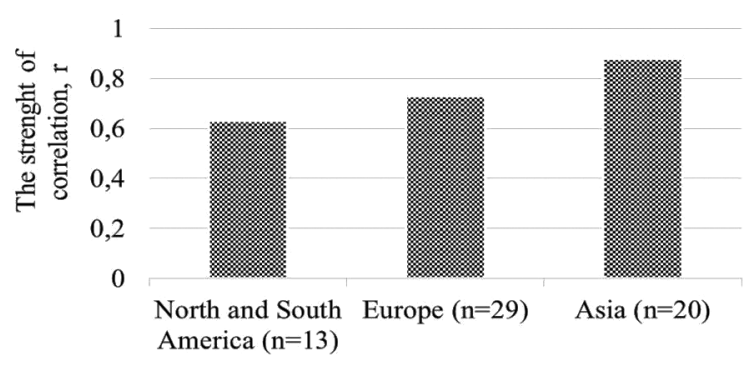

Fig. 1. Influence of freshwater resources on the distribution of population in countries in different regions of the world

According to Fig. 1, the population of most countries of the world is distributed spatially depending on the available water resources, concentrated within the administrative boundaries. For the African continent due to lack of data, it was not possible to obtain statistically significant correlation estimates (Fig. 2).

The correlation between the freshwater supply factor and the population distribution across the world for a mixed sample of 79 countries is not as strong as in each individual region and is $r=0.391$ ( $p=99.9 \%$ ). In view of this, it is fair to assume that the presence of the ocean or the high seas off the coast of the country affects the relationship and quality of water resources and determines the size of human society in these territories.

For example, for landlocked countries (Bolivia, Paraguay, Laos, Nepal, Serbia, Kazakhstan, Zambia, Hungary, Mali, Austria, Afghanistan, Belarus, Switzerland, Slovakia, Uzbekistan, Chad, Mongolia, Slovenia, the Czech Republic, Moldova) and those which do not have access to any seas, without crossing the borders of neighboring states, the reserves of fresh resources do not affect the population. There are probably other factors that affect the population.

Quite different results were obtained for the 59 states that have direct access to the seas or oceans. Thus, there is a weak correlation between freshwater reserves and gross domestic product of the states $(r=0.369 ; p=99 \%)$, as well as with the population $(r=0.372 ; p=99 \%)$ (Fig. 3$)$.

Assessing the impact of freshwater resource factor on population in countries with different levels of development shows that in developed countries (the USA, Canada, Australia, Japan, Norway, New Zealand, France, Italy, Sweden, Iceland, Germany, the United Kingdom, Spain, Finland, Croatia, the Netherlands, Austria, Greece, the Republic of Korea, Portugal, Switzerland, Slovakia, Slovenia, Belgium, the Czech Republic, Israel, Singapore [12]) this figure is higher $(r=0.675$; $p=99.9 \% ; n=27)$ than in developing ones $(r=0.371 ; p=$ $=99 \% ; n=52$ ).

Thus, the freshwater factor influences socio-economic development. Fig. 4 demonstrates the estimation of the force of action of this factor by the method of variance analysis, the methods by Snedekor $(a)$ and Plohinsky $(b)$.

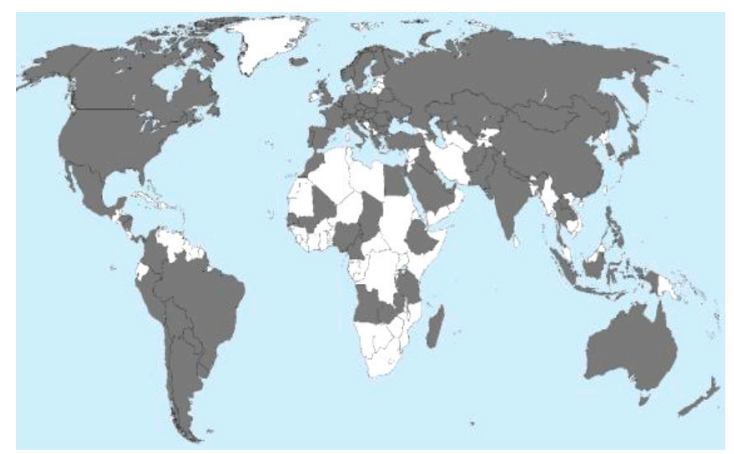

Fig. 2. Territorial limits of assessing the impact of freshwater resources on socio-economic development
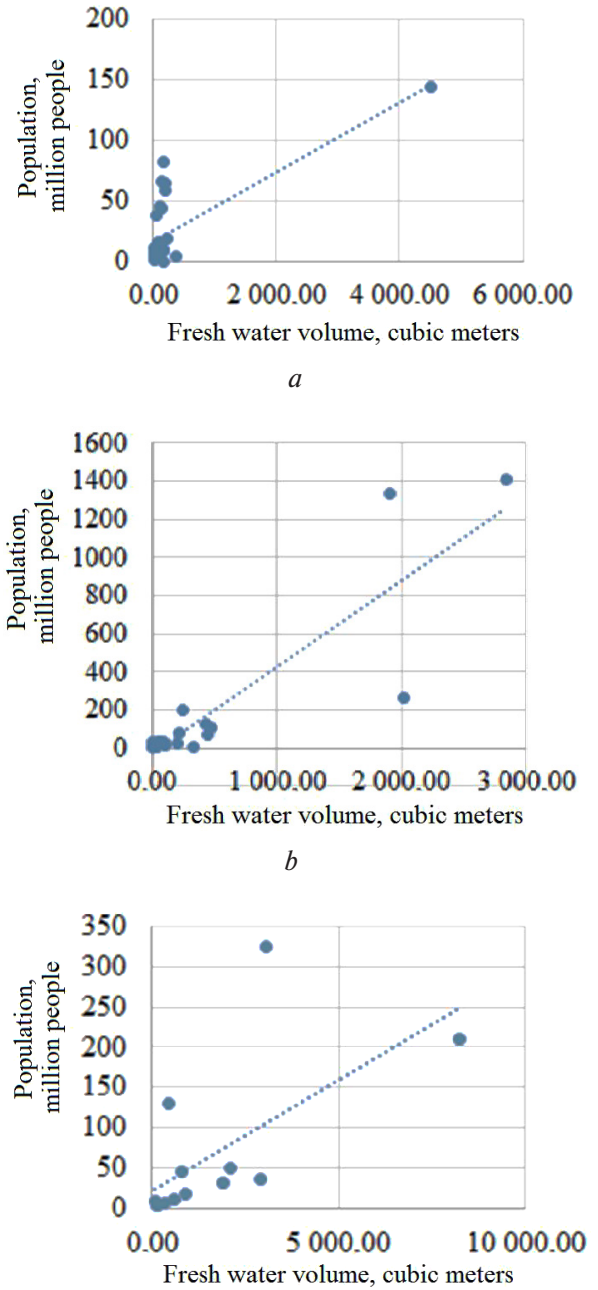

Fig. 3. Bond of fresh water reserves with population distributed within the administrative borders of countries in different regions of the world

According to the results obtained, the available volume of only freshwater resources has a positive effect on the socioeconomic development of states, determining (excluding access to the seas and oceans) the availability of labor resources and the potential for their development by $10-30 \%$.

In accordance with the provisions of the internationally recognized concept of sustainable development, the integrated exploitation of water resources is based on the concept of water as an integral part of the ecosystem, one of the types of natural resources and social and economic benefits, whose nature is determined by its quantity and quality. For this purpose, water

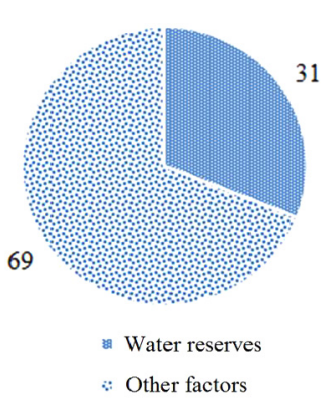

$a$

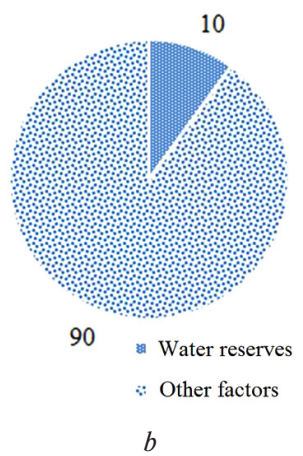

$b$
Fig. 4. The force the freshwater resource factor in forming socioeconomic development 
resources should be conserved. In doing so, it is necessary to take into account the features of the functioning of aquatic ecosystems and the aspects of its restoration of this resource, in order to meet the needs of human activities in water or to bring these activities in line with the resources currently available. In the process of water resources development and use, priority must be given to meeting basic needs and ensuring the conservation of ecosystems [1].

Along with the overriding human needs for water, the United Nations emphasizes that the consumer approach is unsatisfactory [10] and should be re-orientated to "ensure the normal functioning of aquatic ecosystems" and to support the "necessary hydrological regime of swamps, lakes, and coastal areas" [11], "the normal functioning of the natural complex upon which human society is built" [12]. It will be appropriate to add that water treatment and water treatment technologies are practically the same throughout the world [14], but the difference in water quality is shaped, for the most part, by the population's attitude to water and the state to managing this strategic resource [15].

In this context, it is important to emphasize the UN principle that the methods of water resources and ecosystem management, in general, cannot be unified throughout the world, but should be based on the current environmental, social, and economic conditions of a particular country (of course, in terms of the sustainable development goal) [1].

It should be noted that the question of the importance of water resources for the human economy is not exhaustive. U1timately, the question of their indirect impact on human wellbeing through other ecosystem functions (recreational, cultural, regulatory, food) remains poorly understood.

For example, in 2016, about 35.8 million Americans, or $14 \%$ of the US population aged 16 and over, engaged in various types of water-bound fishing. At the same time, 86 million (34\%) observed wildlife. Thus, revenues from these types of ecosystem services related only to water bodies accounted for $1 \%$ of the US gross domestic product - about \$1.9 trillion [16].

Today, in most cases, the cost of water resources is determined by the energy intensity of their extraction, transportation, storage, and use. It is fair to assume that the positive impact of aquatic ecosystems on the socio-economic development of mankind is not limited to the established $30 \%$, but is significantly greater.

Water is known to have social, economic, and environmental value. Therefore, water management should be carried out in such a way as to provide the most satisfactory and sustainable combination.

The UN has also determined that every three out of four jobs in the global labor system are moderately or highly dependent on the availability of water resources. It follows that water scarcity and problems with access to adequate resources and sanitation can significantly hamper economic development and job creation in the coming decades. The UN also emphasizes that about half of the world's workers ( 1.5 billion people) are employed in eight industrial sectors that are directly dependent on water resources [17].

In the current conditions of water consumption, an approach to reassessing the role of aquatic ecosystems in the process of socio-economic development is extremely important. We are talking about the reorientation of consumer priorities from man to natural ecosystem [18] (this has already been implemented at the legislative level in the European Union [19], Australia, Moldova, and Kazakhstan [20]). In other words, by ensuring the functional integrity of aquatic ecosystems and enabling them to meet their own water needs, human society will be able to rely on the sustainable amount of fresh water they produce. And the above is possible only under the condition of careful study on the environmental policies of states, taking into account the peculiarities of local natural conditions. It is advisable to add that most of the post-Soviet countries do not use the concepts of "ecological system" and "ecosystem services" in their legislative framework, which are an integral part of environmental policy and legislation of developed countries.

Water is essential in all spheres of life, and the common goal of humankind is to ensure an adequate supply of water of good quality to the entire population of our planet, while maintaining the hydrological, biological, and chemical functions of ecosystems, adapting human activities to the capabilities of nature.

At the same time, the development and rational use of water resources should be planned comprehensively, that is, on the basis of a systematic approach, and should include environmental, economic, and social factors based on the principle of sustainability.

Taking into account the above, practically valuable and promising research can be considered to assess the significance of the complex of water resources both in the socio-economic development of the states of the world and in its individual aspects. This will allow clarifying not only their economic importance but also the ecosystem value, which is now very underestimated.

Conclusions. It is revealed that most post-Soviet countries do not use the concepts of "ecological system" and "ecosystem services" in their own legislative framework, which today are an integral part of environmental policy and legislation of developed countries. For today, water shortages account for more than $40 \%$ of the world's population. The basic principles for environmental security of aquatic ecosystems are as follows: a water object (surface or underground) is a complex, functionally integrated and self-regulated environmental system. It cannot be considered as a volume with a resource for biological and household and human needs; the priority in water use should be given to its living components, which exist in it and ensure its functional integrity; any aquatic ecosystem must be economically valued not only from the perspective of the available water resources, but also taking into account other ecosystem services, especially the diversity of its biotic components.

The results of the study on the effect of freshwater resources factor on the socio-economic development of countries and regions of the world suggest that there is a strong statistically significant correlation in this system of bonds: Europe $-r=$ $=0.728(n=29 ; p=0.01) ;$ Asia $-r=0.881(n=20 ; p=0.01)$, North and South America $-r=0.63(n=13 ; p=0.05)$.

The quality of water resources and the ability to use seawater are important. The calculation of the force of action of this factor by the methods of Snedekor and Plohinsky provided 39 and $10 \%$, respectively, which proves the strategic importance of freshwater reserves in the socio-economic development of the countries of the world.

The current average planetary water supply of freshwater available to the population is 12.9 thousand $\mathrm{m}^{3}$ per person per year, which is more than 6 times the minimum accepted by the United Nations. Therefore, every state in the world should take into account in the internal environmental policy the regularity of the reproduction and functioning of aquatic ecosystems, and properly evaluate the importance of the relevant ecosystem services.

Acknowledgements. We would like to thank the Erasmus+ Programme of the European Union for supporting the research work in the framework of the Jean Monnet project based on Petro Mohyla Black Sea National University in collaboration with colleagues from Lviv Polytechnic National University and University of Science and Technology, Krakow, Poland.

\section{References.}

1. G20 Leaders Communique Hangzhou Summit, 4-5 September 2016 (2016). Retrieved from http://europa.eu.rapid/pressreleases SIATEMENT-16-2967 en.htm. 
2. Karpinski, M., Pohrebennyk, V., Bernatska, N., Ganczarczyk, J., \& Shevchenko, O. (2018). Simulation of artificial neural networks for assessing the ecological state of surface water. International Multidisciplinary Scientific GeoConference Surveying Geology and Mining Ecology Management, SGEM, 18(2.1), 693-700. https://doi.org/10.5593/sgem2018/2.1/S07.088.

3 Liu, J., Yang, H., Gosling, S. N., Kummu, M., Flörke, M., Pfister, S., ..., \& Oki, T. (2017). Water scarcity assessments in the past, present and future. Earth's Future, 5(6), 545-559.

4. Nechifor, V. (2018). Modelling freshwater resources use and the economic impacts of demand-driven water scarcity. Retrieved from https://www.researchgate.net/publication/327040227 Modelling_freshwater_resources_use and the_economic impacts of demand-driven_water_scarcity.

5. Mitryasova, O., \& Pohrebennyk, V. (2020). Hydrochemical Indicators of Water System Analysis as Factors of the Environmental Quality State. In G., Królczyk, M., Wzorek, A., Król, O., Kochan, J., Su, \& J., Kacprzyk (Eds.). Sustainable Production: Novel Trends in Energy, Environment and Material Systems. Studies in Systems, Decision and Control, 198, 91104. https://doi.org/10.1007/978-3-030-11274-5 7.

6. The United Nations World Water Development Report 2019 (2019). Leaving No One Behind. Paris: UNESCO. Retrieved from https://unesdoc.unesco.org/ark:/48223/pf0000367306.

7. EPI Results (2018). Retrieved from https://epi.envirocenter. yale.edu/epi-topline? country $=\&$ order $=$ field_epi_rank new\&sort $=$ asc

8. The Global Risks Report 2017(2017). Retrieved from https:// www3.weforum.org/docs/GRR17_Report_web.pdf.

9. Glinskiy, V., Serga, L., \& Khvan, M. (2015). Environmental safety of the region: New approach to assessment. Procedia CIRP, 26, 30-34. https://doi.org/10.1016/j.procir.2014.08.017. 10. GNI (current US\$). All Countries and Economies. USA (2019). Retrieved from https://data.worldbank.org/indicator/ ny.gnp.mktp.cd?most recent value desc $=$ true.

11. Population, total. All Countries and Economies. USA (2019). Retrieved from https://data.worldbank.org/indicator/sp.pop. totl.

12. The World Factbook: Drinking Water Source (2017). Retrieved from https://www.cia.gov/library/publications/resources/the-world-factbook/fields/361.html.

13. Human Development Index 2019 (2019). Retrieved from https://hdr.undp.org/sites/default/files/hdr2019.pdf.

14. Jepson, W., Budds, J., Eichelberger, L., Harris, L., Norman, E., O'Reilly, K., \& Young, S. (2017). Advancing human capabilities for water security: A relational approach. Water Security, 1, 46-52. https://doi.org/10.1016/j.wasec.2017.07.001. 15. Mitryasova, O., \& Pohrebennyk, V. (2017). Integrated Environmental Assessment of the Surface Waters Pollution: Regional Aspect. 17 $7^{\text {th }}$ International Multidisciplinary Scientific GeoConference SGEM 2017, 17, (pp. 235-242). https://doi. org/10.5593/SGEM2017H/33/S12.029.

16. Mitryasova, O., Pohrebennyk, V., Kochanek, A., \& Stepanova, O. (2017). Environmental Footprint Enterprise as Indicator of Balance it's Activity. 17 ${ }^{\text {th }}$ International Multidisciplinary Scientific Geoconference SGEM 2017, 17, (pp. 371-378). https://doi.org/10.5593/sgem2017/51.

17. USFWS (2016). National Survey of Fishing, Hunting, and Wildlife Associated Recreation. Retrieved from https://www. fws.gov/wsfrprograms/subpages/nationalsurvey/nat_survey2016.pdf.

18. Bezsonov, Ye., Mitryasova, O., Smyrnov, V., \& Smyrnova, S. (2017). Influence of the South-Ukraine electric power producing complex on the ecological condition of the Southern Bug River. Eastern-European Journal of Enterprise Technologies, 4/10(88), 20-28. https://doi.org/10.15587/1729-4061.2017.108322.

19. Water drives job creation and economic growth, says new $U N$ report (2016). Retrieved from https://unesdoc.unesco.org/ ark:/48223/pf0000243938.

20. Thomas, W. Hertel, \& Jing Liu (2016). Implications of water scarcity for economic growth. Environment working paper,
France, 109, Retrieved from https://www.oecd-ilibrary.org/ docserver/5jlssl611r32-en.pdf?expires $=1588082362 \& i d=i d \& a$ ccname $=$ guest $\&$ checksum $=$ D1F550D30D6FAB2FF0088AC 9D65A265D

\section{Екологічна політика в галузі безпеки водних ресурсів в ЄС, Україні та інших країнах, що розвиваються}

\author{
О. П. Мітрясова ${ }^{1}$ В. Д. Погребенник ${ }^{2}$, О. С. Петров ${ }^{3}$, \\ С. М. Безсонов ${ }^{1}$, В. М. Смирнов ${ }^{1}$
}

1 - Чорноморський національний університет імені Петра Могили, м. Миколаїв, Україна, e-mail: eco-terra@ukr. net

2 - Національний університет «Львівська політехніка», м. Львів, Україна

3 - Університет науки та технологій, м. Краків, Республіка Польща

Мета. Визначення ключових принципів екологічної безпеки водних екосистем за умов сталого використання природних ресурсів і соціально-економічного розвитку.

Методика. Порівняльний аналіз та системний підхід.

Результати. Проаналізовані провідні аспекти управління водними ресурсами в різних країнах світу в контексті положень концепції сталого розвитку. Порівняння країн із різним рівнем розвитку дозволило визначити ключові методологічні положення, що реалізуються в екологічній політиці використання води. Запропоновано підхід до визначення граничних показників впливу на довкілля. Виявлено, що більшість пострадянських країн не використовують поняття «екологічна система» та «екосистемні послуги» у власній законодавчій базі, що сьогодні є невід'ємною частиною екологічної політики й законодавства розвинених країн. Основні принципи екологічної безпеки водних екосистем такі: водний об'єкт (поверхневий або підземний) це складна, функціонально інтегрована й саморегульована екологічна система. Його не можна розглядати як об'єм із ресурсом для біологічних і побутових потреб; пріоритет у використанні води слід віддавати ії живим компонентам, які існують у ній і забезпечують іiї функціональну цілісність; будь-яка водна екосистема повинна бути економічно оцінена не тільки з точки зору наявних водних ресурсів, але і з урахуванням інших екосистемних послуг, особливо різноманітності її біотичних компонентів. Усі ці принципи й підхід, викладений у рукописі в разі впровадження до вітчизняного законодавства, дозволять досягти прогресу в галузі екологічної безпеки водних екосистем і сталого соціального економічного розвитку.

Наукова новизна. Удосконалено підхід щодо визначення ефективності екологічної політики в галузі безпеки водних ресурсів через кореляційний аналіз показників водопостачання й чисельності населення.

Практична значимість. Результати досліджень дозволяють кількісно оцінювати менеджмент водних ресурсів. Результати дослідження впливу чинника водних ресурсів на соціально-економічний розвиток країн і регіонів світу свідчать про наявність сильної статистично значущої кореляції.

Ключові слова: водна екосистема, водні ресурси, безпека водних ресурсів, екологічна політика, сталий розвиток

\section{Экологическая политика в области безопасности водных ресурсов в ЕС, Украине и других развивающихся странах}

\author{
Е. П. Митрясова ${ }^{1}$, В. Д. Погребенник ${ }^{2}$, А. С. Петров ${ }^{3}$, \\ Е. Н. Безсонов ${ }^{1}$, В. Н. Смирнов
}


1 - Черноморский национальный университет имени Петра Могилы, г. Николаев, Украина, e-mail: eco-terra@ ukr.net

2 - Национальный университет «Львовская политехника», г. Львов, Украина

3 - Университет науки и технологий, г. Краков, Республика Польша

Цель. Определение ключевых принципов экологической безопасности водных экосистем в условиях устойчивого использования природных ресурсов и социальноэкономического развития.

Методика. Сравнительный анализ и системный подход.

Результаты. Проанализированы ведущие аспекты управления водными ресурсами в различных странах мира в контексте положений концепции устойчивого развития. Сравнение стран с разным уровнем развития позволило определить ключевые методологические положения, которые реализуются в экологической политике использования воды. Предложен подход к определению предельных показателей воздействия на окружаюшую среду. Выявлено, что большинство постсоветских стран не используют понятие «экологическая система» и «экосистемные услуги» в своей законодательной базе, которые сегодня являются неотъемлемой частью экологической политики и законодательства развитых стран. Основные принципы экологической безопасности водных экосистем такие: водный объект (поверхностный или подземный) - это сложная, функционально интегрированная и саморегулируемая экологическая систе- ма. Его нельзя рассматривать как объем с ресурсом для биологических и бытовых потребностей; приоритет в использовании воды следует отдавать живым компонентам, которые существуют в ней и обеспечивают ее функциональную целостность. Любая водная экосистема должна быть экономически оценена не только с точки зрения имеющихся водных ресурсов, но и с учетом других экосистемных услуг, особенно разнообразия ее биотических компонентов. Все эти принципы и изложенный подход, в случае внедрения в отечественное законодательство, позволят достичь прогресса в области экологической безопасности водных экосистем и устойчивого социального экономического развития.

Научная новизна. Усовершенствован подход, определяющий эффективность экологической политики в области безопасности водных ресурсов через корреляционный анализ водопотребления и численности населения.

Практическая значимость. Результаты исследований позволяют количественно оценивать менеджмент водных ресурсов. Результаты исследования влияния фактора пресноводных ресурсов на социально-экономическое развитие стран и регионов мира позволяют предположить, что существует сильная статистически значимая корреляция в этой системе связей.

Ключевые слова: водная экосистема, водные ресурсы, безопасность водных ресурсов, экологическая политика, устойчивое развитие

Recommended for publication by O.A. Nahurskyi, Doctor of Technical Sciences. The manuscript was submitted 07.09.20. 